\title{
High Genetic Diversity in the Long-Tailed Ground Squirrel (Spermophilus undulatus) Population on Olkhon Island: A Natural Gene Bank or the Consequences of Long-Term Isolation?
}

\author{
S. V. Titov ${ }^{a}$, L. E. Savinetskaya ${ }^{b}$, and A. V. Tchabovsky $b$ \\ Presented by Academician D.S. Pavlov April 28, 2009
}

Received April 30, 2009

DOI: $10.1134 / \mathrm{S} 001249660906012 \mathrm{X}$

Long-term isolation of populations (in particular, island ones) usually results in gene flow limitation, losses in genetic diversity, decrease in the heterozygosity level, and increase in the inbreeding level [4, 7]. This, in turn, decreases their resistance to external factors under changing environmental conditions and increases the risk of extinction [5]. In species with limited dispersion, isolation disturbs the balance between gene drift and flow and many lead to differentiation of populations and formation of specific genetic peculiarities [6].

On the other hand, the main island populations may serve as a refugium for preservation of genetic material if the mainland populations for some reasons experience strong selection pressure or influence of eliminating factors. In this case, island populations should be given a special nature-conservation status [8].

The long-tailed ground squirrel (Spermophilus undulatus) in Cisbaikalia inhabits steppe areas divided by forest both on the mainland and on Olkhon Island (the length of the island is $73 \mathrm{~km}$, and the maximum width is $15 \mathrm{~km}$ ). The strait separating the island from the mainland, 2 to $17 \mathrm{~km}$ wide, serves as a barrier isolating the island population, because it freezes in the period when ground squirrels usually hibernate. In this work, we studied the genetic structure and genetic diversity of populations on long-tailed ground squirrels in Cisbaikalia (on the mainland and on Olkhon Island) by microsatellite analysis to assess the status of the island population, the degree of its isolation, and possible routes of its origin.

Samples for analysis were obtained in June and July of 2007 and 2008 from unrelated individuals of three

\footnotetext{
${ }^{a}$ Belinskii Penza State Pedagogical University, Penza, Russia

${ }^{b}$ Severtsov Institute of Ecology and Evolution, Russian Academy of Sciences, Leninskii pr. 33, Moscow, 119071 Russia
}

populations: from Olkhon Island ( $n=34$; eight settlements; distance between collection points, 0.2$62.5 \mathrm{~km}$ ), from the Small Sea shore (across a strait 1.5-2.0 wide from the island; $n=16$; five settlements; $0.2-17.8 \mathrm{~km}$ ), and from the Goloustnaya River mouth (approximately $150 \mathrm{~km}$ southeast of Olkhon Island and the Small Sea Shore; $n=31$; six settlements; 0.2$9.5 \mathrm{~km})$. The settlements of ground squirrels on the Small Sea shore and in the Goloustnaya River mouth are strongly isolated by taiga sites and are confined to steppe or riparian meadow vegetation sites. The settlements of ground squirrels on Olkhon Island are located in steppe sites in the northern, central, and southern parts of the island, being separated by large forest stands.

Samples of ground squirrel liver were fixed in $96 \%$ ethanol. Molecular-genetic analysis of microsatellite DNA was performed using a system of primers specifically developed for ground squirrels (STR3 D: 5'TGGTCCCAGTTAGTGGATTAC-3', STR3 R: 5'CAAGTAAAGGGTCGTGGTGTGT-3') for the synthesis of the DNA fragment containing microsatellite repeat. PCR was performed in $25 \mu \mathrm{l}$ of a reaction mixture containing $50 \mathrm{mM}$ Tris- $\mathrm{HCl}(\mathrm{pH} 8.9), 20 \mathrm{mM}$ ammonium sulfate, $20 \mu \mathrm{M}$ EDTA, $150 \mu \mathrm{g} / \mathrm{ml}$ bovine serum albumin, a mixture of four deoxynucleoside triphosphates $(200 \mu \mathrm{M}$ of each), $2 \mathrm{mM}$ magnesium chloride, $15 \mathrm{pmol}$ of each primer, $2 \mathrm{U}$ of Taq polymerase, and $0.1-0.2 \mu \mathrm{g}$ DNA. Amplification was performed under the following conditions: $94^{\circ} \mathrm{C}$ for $1 \mathrm{~min}, 60^{\circ} \mathrm{C}$ for $1 \mathrm{~min}$, and $72^{\circ} \mathrm{C}$ for $1 \mathrm{~min}$ ( 40 cycles). The obtained fragments of microsatellite DNA were analyzed only by PAGE in $8 \%$ polyacrylamide gel with subsequent staining with ethidium bromide and visualization under UV light.

The genetic diversity and genetic structure of populations and the genetic distances between them were estimated using multilevel F statistics [9], in particular, the inbreeding coefficient and the fixation index (the measure of differentiation between populations varies from 0 (no differentiation) to 1 (complete differ- 
Table 1. Occurrence $(N)$ of different STR3 alleles in the island and mainland populations. The alleles specific for individual populations are underlined

\begin{tabular}{l|c|c|c|c|c}
\hline \multirow{2}{*}{ Allele } & \multirow{2}{*}{$\begin{array}{c}\text { Number } \\
\text { of CCT } \\
\text { repeats }\end{array}$} & $\begin{array}{c}\text { Weight, } \\
\text { bp }\end{array}$ & \multicolumn{3}{|c}{ Population } \\
\cline { 4 - 6 } & $\begin{array}{c}\text { Olkhon } \\
\text { Island }\end{array}$ & $\begin{array}{c}\text { Small } \\
\text { Sea }\end{array}$ & $\begin{array}{c}\text { Goloust- } \\
\text { noe }\end{array}$ \\
\hline str1 & 0 & 150 & $\underline{4}$ & & \\
str2 & 1 & 153 & $\underline{8}$ & & \\
str3 & 2 & 156 & $\underline{6}$ & & \\
str4 & 3 & 159 & 7 & & 9 \\
str5 & 4 & 162 & 4 & & 17 \\
str6 & 5 & 165 & 1 & 1 & 4 \\
str7 & 6 & 168 & 10 & 1 & \\
str8 & 7 & 171 & 8 & 5 & 6 \\
str9 & 8 & 174 & 6 & 6 & 26 \\
str10 & 9 & 177 & 6 & 7 & \\
str11 & 10 & 180 & 4 & 8 & \\
str12 & 11 & 183 & 3 & 3 & \\
str13 & 12 & 186 & 1 & & \\
str14 & 13 & 189 & & 1 & \\
Total & & & 68 & 32 & 62 \\
\hline
\end{tabular}

entiation, which means that subpopulations do not carry the same alleles).

The molecular-genetic analysis of samples from the three populations of the long-tailed ground squirrel revealed considerable allelic polymorphism of microsatellite DNA for the STR 3 system: a total of 14 alleles (str 1-str14). The greatest diversity and specificity of the set of alleles was found for the population from Olkhon Island, in which 13 of 14 alleles were detected (Table 1). Four of them proved to be specific (occurring only in this population). In the nearby mainland population from the Small Sea shore, 8 of 14 alleles were found, only one of which was specific. The population in the Goloustnaya River Mouth had the least diversity: only 5 of 14 alleles were found in it, none of which was specific. In general, the interpopu- lation genetic structure is well pronounced and the degree of differentiation between the populations corresponds to the moderate level according to Wright's tests [9] at a sufficiently high inbreeding degree (Table 2). All three populations had lower observed proportions of heterozygotes compared to the expected values calculated for unlimited breeding (Table 2). However, unlike the mainland populations, only in the island population, which had the minimum heterozygosity level, these differences were statistically significant (according to the two-tailed Fisher's test, $p<0.001$ ). Possibly, this is determined by a higher degree of isolation of some settlements on Olkhon Island.

The specificity and high diversity of the set of alleles in the ground squirrels from Olkhon Island (Table 1), the high expected heterozygosity combined with a low observed heterozygosity (Table 2) and a high inbreeding index (Table 3 ), as compared to the mainland populations, are indicative of the long-term isolation of the island population and apparently its relic origin. It can be assumed that the long-tailed ground squirrel population on Olkhon Island formed as a result of separation from the relic mainland population as a result of formation of the Small-Sea strait in Pleistocene (0.7-0.8 million years ago), which separated the island from the mainland $[1,3]$ and became a difficult-to-overcome barrier for hibernating ground squirrels.

Fossil remains of ground squirrels are known on the territory of modern Baikal Depression beginning from Miocene and Pliocene [3]. In mid-Pliocene, open herbaceous steppe communities were widespread in this area, whereas dark coniferous forests had a less important role [2]. As a result of periodic glaciation and climatic cooling, the steppe vegetation on the coastal mainland part was repeatedly replaced with taiga and forest-steppe vegetation [2,3]. As a result, ground squirrel populations might periodically experience fragmentation and a strong selection pressure that might cause their complete extinction.

Despite the periodic fluctuations in the distribution of steppe communities, dark coniferous forests have been the initial and dominant vegetation type in the entire Cisbaikalia during the whole period of time [2].

Table 2. Genetic structure of island and mainland populations of the long-tailed ground squirrel

\begin{tabular}{l|c|c|c|c|c}
\hline \multirow{2}{*}{ Heterozygosity } & \multicolumn{3}{|c|}{ Population } & \multirow{2}{*}{ Mean } & $\begin{array}{c}\text { For three popula- } \\
\text { tions (region) }\end{array}$ \\
\cline { 2 - 5 } & Olkhon Island & Small Sea & Goloustnoe & & 0.543 \\
\hline Observed, $H_{O}$ & 0.47 & 0.63 & 0.58 & $0.559\left(H_{I}\right)$ & $0.881\left(H_{T}\right)$ \\
Expected, $H_{E}$ & 0.90 & 0.82 & 0.71 & $0.812\left(H_{S}\right)$ & 0.312 \\
$F_{I S},\left(H_{S}-H_{I}\right) / H_{S}$ & & & & & 0.078 \\
$F_{S T},\left(H_{T}-H_{S}\right) / H_{T}$ & & & & & \\
\hline
\end{tabular}


Table 3. Genetic differentiation of populations of the longtailed ground squirrel

\begin{tabular}{l|c|c|c}
\hline \multirow{2}{*}{ Heterozygosity } & \multicolumn{3}{|c}{ Mean for populations } \\
\cline { 2 - 4 } & $\begin{array}{c}\text { Olkhon } \\
\text { Island }+ \\
\text { Small Sea }\end{array}$ & $\begin{array}{c}\text { Olkhon } \\
\text { Island }+ \\
\text { Goloustnoe }\end{array}$ & $\begin{array}{c}\text { Goloust- } \\
\text { noe }+ \\
\text { Small Sea }\end{array}$ \\
\hline Observed, $H_{I}$ & 0.548 & 0.603 & 0.570 \\
Expected, $H_{S}$ & 0.861 & 0.766 & 0.763 \\
$F_{I S},\left(H_{S}-H_{I}\right) / H_{S}$ & 0.364 & 0.213 & 0.254 \\
$F_{S T},\left(H_{T}-H_{S}\right) / H_{T}$ & 0.046 & 0.118 & 0.060 \\
\hline
\end{tabular}

At the same time, steppe areas appeared on Olkhon Island as a result of autochthonic development of xerophilic communities that had stably existed here beginning from Paleogene [2]. Depending on climatic fluctuations in Pleistocene, the steppe flora was only enriched in tundra species, with period formation of tundra-steppe complexes, which are apparently suitable for ground squirrels. Thus, the island might serve as a refugium for ground squirrels under conditions of periodically changing vegetation of Cisbaikalia. The coastal mainland populations, which periodically experience strong selection pressure, could recover at the expense of rare migrants from the island, where steppe communities were stably retained, which managed to overcome the strait. This hypothesis is confirmed by the high similarity between the island population and the nearby mainland population from the Small Sea shore as compared to the geographically and genetically remote population from the Goloustnaya River Mouth (compare $F_{S T}$, Table 3 ).

Another explanation for the higher diversity and specificity of the set of alleles in the island population compared to the mainland populations may be the occurrence, under conditions of a long-term isolation, of new allelic variants of microsatellite DNA as a result of loss of some satellite repeats during replication. This assumption is confirmed by the small number of repeats (str2, CCT; str3, CCT CCT) or their complete absence (str 1) in three of four specific STR3 alleles found in the population of Olkhon Island (Table 1). In this case, specific alleles should be regarded as formed de novo and accumulated as a result of gene drift under conditions of a limited gene flow rather than relic ones.
Regardless of the factor that determined the high genetic diversity and specificity of the population of long-tailed ground squirrels on Olkhon Island, it should be given a special nature-conservation status as a natural storage of genetic material.

\section{ACKNOWLEDGMENTS}

We are especially grateful to A.I. Kryukov and personnel of OOO Gigienist for their help in organization and performance of field research and to administration of the Pribaikal'skii National Park for the support in performing the study. We are grateful to all who helped us to collect material: D.B. Vasil'ev, D.V. Pozhariskii, V.A. Kryukov, V.S. Shved, and S.V. Pavlova. Thanks are also due to researchers and graduate and undergraduate students of the Department of Zoology and Ecology, Belinskii Penza State Pedagogical University for their help in performing molecular-genetic analysis.

This study was supported by the Russian Foundation for Basic Research (project nos. 07-04-00721a and 08-04-10085k), the Biological Diversity program of the Presidium of the Russian Academy of Sciences and the Federal Target Program "Research and Scientific Educational Specialists of Innovative Russia" (project no. 2009-1.1-141-063-02).

\section{REFERENCES}

1. Agafonov, B.P. and Akulov, N.I., Izv. Akad. Nauk, Ser. Geogr., 2006, no. 5, pp. 101-108.

2. Belov, A.V. et al., Geogr. Prir. Res., 2006, no. 3, pp. 518.

3. Galazii, G.I., Ozero Baikal: proshloe, nastoyashchee, budushchee. Atlas (Lake Baikal: The Past, Present, and Future: An Atlas), Irkutsk, 2005.

4. Frankham, R., Biol. Conserv., 1998, vol. 12, no. 3, pp. 665-675.

5. Frankham, R., C. R. Acad. Sci. Biol., 2003, no. 326, pp. 22-S29.

6. Jordan, M.A. and Snell, H.L., Mol. Ecol., 2008, vol. 17, no. 5, pp. 1224-1237.

7. Ohnishi, N. et al., Conserv. Gen., 2007, vol. 8, no. 6, pp. 1331-1337.

8. Vega, R. et al., Biol. Conserv., 2007, vol. 137, no. 2, pp. 210-222.

9. Wright, S., Evolution and the Genetics of Populations, vol. 4: Variability within and among Natural Populations, Chicago: Univ. Chicago Press, 1978. 